\title{
PENGARUH MODEL QUANTUM TEACHING BERBASIS TRI HITA KARANA TERHADAP KOMPETENSI PENGETAHUAN PPKN SISWA KELAS V
}

\author{
Md Ayu Candra Dewi ${ }^{1}$, I G A Agung Sri Asri ${ }^{2}$, Ni Wyn Suniasih ${ }^{3}$ \\ 1'2'3Jurusan Pendidikan Dasar, Universitas Pendidikan Ganesha \\ e-mail: ayu.candra.dewi2@undiksha1.ac.id, igaagungsri@undiksha.ac.id², \\ niwayan.suniasih@undiksha.ac.id ${ }^{3}$
}

\begin{abstract}
ABSTRAK
Penelitian ini bertujuan untuk mengetahui pengaruh model quantum teaching berbasis Tri Hita Karana terhadap kompetensi pengetahuan PPKn kelas V SD Gugus Kolonel I Gusti Ngurah Rai Denpasar Utara. Penelitian ini tergolong sebagai penelitian eksperimen dengan rancangan post test only control group design. Populasi dalam penelitian ini adalah seluruh siswa kelas $\mathrm{V}$ berjumlah 470 siswa. Penentuan sampel penelitian ini dilakukan dengan teknik simple random sampling yang berjumlah 70 orang. Pengumpulan data dilakukan dengan tes pilihan ganda. Metode analisis data yang digunakan adalah uji t. Hasil penelitian berdasarkan analisis data diperoleh harga $t_{\text {hitung }}=8,239>\mathrm{tt}_{\mathrm{abel}}=2,00$ dengan taraf signifikan $5 \%$ dan $\mathrm{dk}=68$, maka $\mathrm{H}_{0}$ di tolak dan $\mathrm{H}_{\mathrm{a}}$ di terima. Hal ini membuktikkan bahwa terdapat perbedaan yang signifikan kompetensi pengetahuan PPKn antara kelompok yang mendapatkan pembelajaran model quantum teaching berbasis Tri Hita Karana dengan kelompok kelompok yang mendapatkan pembelajaran konvensional pada siswa kelas V SD Gugus Kolonel I Gusti Ngurah Rai Denpasar Utara tahun pelajaran 2018/2019. Berdasarkan temuan penelitian, disimpulkan bahwa terdapat pengaruh model quantum teaching berbasis Tri Hita Karana terhadap kompetensi pengetahuan PPKn kelas V SD Gugus Kolonel I Gusti Ngurah Rai Denpasar Utara. Nilai rata-rata juga menunjukan bahwa kompetensi pengetahuan PPKn yang diperoleh siswa kelas eksperimen $\bar{X}=79,02>\bar{X}=69,38$ siswa kelompok kontrol. Jadi dapat disimpulkan model quantum teaching berbasis Tri Hita Karana berpengaruh terhadap kompetensi pengetahuan PPKn siswa kelas V SD Gugus I Gusti Ngurah Rai Denpasar Utara tahun ajaran 2018/2019.
\end{abstract}

Kata-kata kunci: model quantum teaching, tri hita karana, kompetensi pengetahuan PPKn

\begin{abstract}
This study aims to determine the effect of the quantum teaching model based on Tri Hita Karana on the knowledge competence of class V PPKn Elementary School Colonel I Gusti Ngurah Rai, North Denpasar. This study is classified as an experimental study with a post test only control group design. The population in this study were all students in class $V$ totaling 470 students. Determination of this research sample was carried out by simple random sampling technique which amounted to 70 people. Data collection is done by multiple choice tests. The data analysis method used is the $t$ test. The results of the study based on data analysis obtained the price of tcount $=8.239>t$ table $=2.00$ with a significant level of $5 \%$ and $\mathrm{dk}=68$, then $\mathrm{HO}$ is rejected and $\mathrm{Ha}$ is accepted. This proves that there are significant differences in the PPKn knowledge competencies between the groups that received the Tri Hita Karana based quantum teaching learning model and the group that received conventional learning in fifth grade students of Elementary School Colonel I Gusti Ngurah Rai Denpasar Utara 2018/2019 academic year. Based on the findings of the study, it
\end{abstract}


was concluded that there was the influence of the Tri Hita Karana based quantum teaching model on the knowledge competency of class V PPKn Elementary School Colonel I Gusti Ngurah Rai North Denpasar. The average score also shows that the PPKn knowledge competencies obtained by the experimental class students $X=79.02>X=69.38$ control group students. So it can be concluded that the quantum teaching model based on Tri Hita Karana has an effect on the knowledge competence of PPKn fifth grade students of SD Gugus I Gusti Ngurah Rai Denpasar Utara academic year 2018/2019.

Keywords: quantum teaching model, tri hita karana, PPKn knowledge competency

\section{PENDAHULUAN}

Pendidikan memiliki peran sangat penting dalam pembangunan bangsa, kiranya tidak ada yang meragukan. Namun tentu harus dipahami, pendidikan yang mampu mendukung pembangunan adalah pendidikan yang bermutu, yaitu pendidikan yang mampu mengembangkan potensi peserta didik, sehingga yang bersangkutan mampu menghadapi dan memecahkan problema kehidupan yang dihadapinya. Dalam upaya meningkatkan mutu pendidikan, mutu guru merupakan salah satu komponen yang mempunyai peran sangat penting. Salah satu upaya untuk meningkatkan mutu pendidikan di sekolah adalah dengan cara perbaikan proses pembelajaran. Berbagai konsep dan wawasan baru tentang pembelajaran di sekolah telah muncul dan berkembang seiring pesatnya ilmu pengetahuan dan teknologi.

Triwiyanto (2014:113) menyatakan, Pendidikan merupakan usaha sadar dalam mewujudkan suasana belajar dan proses pembelajaran agar peserta didik secara aktif dapat mengembangkan potensinya untuk memiliki kekuatan spiritual keagamaan, pengendalian diri, kecerdasan, akhlak mulia, serta keterampilan yang diperlukan dirinya sendiri. Keberhasilan pendidikan dipengaruhi oleh perubahan dan pembaharuan segala komponen pendidikan. Perubahan yang didorongoleh perkembangan zaman menjadi dasar munculnya ancaman, tantangan, hambatan dan gangguan (ATHG) bagi seluruh masyarakat, tidak terkecuali masyarakat Indonesia.Dalam hal ini pembelajaran berlangsung sebagai suatu proses saling mempengaruhi antara guru dan siswa. Namun yang sering kita lihat dalam kenyataan, kegiatan yang terjadi adalah guru mengajar dan siswa belajar.

Berdasarkan observasi yang dilaksanakan pada hari Rabu tanggal 30 Januari 2019, salah satu wali kelas V (Putu Andi Surya Prayoga, S.Pd M.Pd) menyatakan bahwa penguasaan kompetensi pengetahuan PPKn siswa kelas V SDN 3 ubung Gugus Kolonel I Gusti Ngurah Rai Denpasar Utara masih rendah. Namun, terdapat permasalahan yang terletak pada kurangnya kemampuan menanya dan mengomunikasikan pada saat proses pembelajaran. Kondisi ini tentu akan menciptakan kurangnya partisipasi siswa sehingga beberapa siswa menjadi kurang aktif dalam pembelajaran.

Pembelajaran PPKn di setiap lembaga persekolahan memerlukan strategi pembelajaran yang dapat memberikan kemampuan pemecahan masalah kepada para siswa secara individual. Model atau strategi pembelajaran yang dikembangkan para ahli dalam usaha mengoptimalkan hasil belajar siswa, diantaranya adalah model Quantum Teaching. Quantum adalah interaksi yang mengubah energi menjadi cahaya. Menurut Bobbi DePorter (dalam Thobroni, 2015), Quantum teaching berfokus pada hubungan dinamis dalam lingkungan kelas. Interaksi yang mendirikan landasan dan kerangka untuk belajar. Quantum teching adalah orkestrasi bermacam-macam interaksi yang ada didalam dan sekitar momen belajar, seperti mencakup unsur-unsur untuk belajar efektif yang mempengaruhi kesuksesan siswa. Quantum teaching menguraikan cara-cara baru yang memudahkan proses belajar lewat pemaduan unsur seni dan pencapaian-pencapaian yang terarah. "Dengan menggunakan Quantum teaching maka guru akan mampu menggabungkan keistimewaankeistimewaan belajar menuju bentuk perencanaan pengajaran yang dapat melejitkan siswa" (Bobbi DePotter, 2014:31). Berdasarkan pemaparan tersebut dapat dikatakan bahwa Quantum teaching adalah usaha maksimal yang dilakukan oleh warga belajar untuk 
meningkatkan pengalaman dan hasil belajar dengan menyertakan segala potensi yang ada pada dalam diri dan lingkungan.

Model Quantum teaching sangat tepat diterapkan dalam K13 karena dapat memberikan suasana baru dalam proses pembelajaran. Model Quantum teaching menekankan aktivitas siswa secara maksimal untuk mencari dan menemukan sehingga siswa ditempatkan sebagai pusat pembelajaran. Pembelajaran akan menjadi lebih bermakna jika dalam prosesnya siswa diperlakukan sebagai subjek pembelajaran dan orientasi proses berada di pihak siswa. Apabila hal tersebut dapat terus dilakukan, maka siswa akan mencapai keberhasilan dalam belajarnya.Pembelajaran yang dilakukan di sekolah juga perlu disesuaikan dengan semua perkembangan yang terjadi di masyarakat agar siswa mampu untuk tetap bersaing dengan era globalisasi ini. Namun, pembelajaran yang dilakukan harus tetap dijaga keseimbangan suatu hubungan satu sama lain yang ada pada setiap daerah di Indonesia. Mengingat betapa pentingnya mempertahakan hubungan yang seimbang dan harmonis, khususnya bagi masyarakat Bali, yang selama ini dirasa semakin tergerus oleh arus globalisasi sehingga mengakibatkan generasi muda di Bali tidak begitu mengenal keseimbangan dua hal yang selalu berbeda, tetapi tidak dapat di pisahkan., yaitu Rwa Bhineda. Oleh karena itu, maka dalam penerapan model Quantum teaching akan dilaksanakan dengan berbasis Tri Hita Karana.Untuk menjaga keseimbangan suatu hubungan satu sama lainnya perlu mengadakan hubungan yang seimbang dan harmonis anatara manusia dengan Tuhan yang disebut Parahyangan, manusia dengan manusia yang disebut Pawongan, dan manusia dengan lingkungan alam kita sekitarnya yang disebut Palemahan. Ketiga hubungan yang seimbang dan harmonis itu merupakan bagian-bagian dari Tri Hita Karana. Tri Hita Karana artinya tiga hubungan yang seimbang dan harmonis yang menyebabkan kebahagiaan atau kesejahteraan.

Pengintegrasian materi dan model pembelajaran PPKn yang berorientasi Tri Hita Karana merupakan salah satu bentuk inovasi pembelajaran yang perlu dikembangkan terutama bagi guru dalam upaya meningkatkan efektivitas pembelajaran disekolah, terutama di jenjang pendidikan SD karena hal ini sejalan dengan pengembangan kurikulum 2013 yang sedang diberlakukan di Indonesia saat ini penerapan modelQuantum teaching berbasis Tri Hita Karana nantinya diharapkan akan menambah tingkat pemahaman siswa sehingga memberikan pengaruh yang baik terhadap kompotensi pengetahuan siswa dalam mata pelajaran PPKn serta menciptakan karakter yang kuat dalam diri anak. Menurut Ihsan (2017) Pendididikan pancasila dan kewarganegaraan dalam Konseptualisasi yaitu komponen-komponen yang saling berinterelasi. Secara substantif, mata pelajaran pendidikan pancasila dan kewarganegaraan mempelajari prinsip-prinsip sekaligus mempraktekkan "democratic governance and citizens".

Berpijak pada latar belakang masalah tersebut, untuk mengetahui seberapa jauh model Quantum teaching tersebut dapat berpengaruh terhadap kompotensi pengetahuan PPKn perlu dibuktikan dengan penelitian yang berjudul "Pengaruh Model Quantum Teaching Berbasis Tri Hita Karana terhadap Kompetensi Pengetahuan PPKn Kelas V SD Gugus Kolonel I Gusti Ngurah Rai Denpasar Utara".

\section{METODE}

\begin{tabular}{|lll|}
\hline $\mathrm{R}$ & $\mathrm{X}$ & $\mathrm{O} 1$ \\
$\mathrm{R}$ & & $\mathrm{O} 2$ \\
\hline
\end{tabular}

Gambar 1.

Rancangan "Post Test Only

Control Group Design"

(Sumber : Dantes, $2017:$ 17)

Desian Eksperimen yang digunakan dalam
penelitian ini adalah dengan rancangan "Post Test Only
Control Group Design".Dalam desain ini terdapat dua
kelompok, yaitu kelompok eksperimen dan kelompok

kontrol.

Keterangan :

$\mathrm{R}=$ Random

O1 = Posttest pada kelompok eksperimen

$\mathrm{O} 2$ = Posttes pada kelompok control 


\section{$\mathrm{X}=$ Perlakuan (treatment) pada kelas eksperimen}

Kelompok eksperimen diberikan pembelajaran dengan menerapkan model quantum teaching berbasis Tri Hita Karana, sedangkan untuk kelompok kontrol pembelajaran secara konvensional. Pada Penelitian ini di akhir perlakuan diberikan posttest yang hasilnya digunakan untuk uji kesetaraan kelompok eksperimen dan kelompok kontrol, dan untuk analisis data dalam uji normlitas juga homogenitas.

Populasi dan sampel dalam suatu penelitian memiliki hubungan yang saling berkaitan. Menurut Dantes (2012:37), "populasi dapat didefinisikan sebagai sejumlah kasus yang memenuhi kriteria tertentu yang ditentukan peneliti". Kasus-kasus bisa berbentuk peristiwa-peristiwa, manusia, hewan, tumbuh-tumbuhan dan sebagainya. Menurut Sugiyono (2010:80), "Populasi merupakan wilayah generalisasi yang terdiri atas obyek/subyek yang mempunyai kualitas dan karakteristik tertentu yang diterapkan oleh peneliti untuk dipelajari dan kemudian ditarik kesimpulannya". Berdasarkan kedua pendapat di atas, dapat disimpulkan bahwa populasi adalah objek atau subjek yang telah ditetapkan untuk dipelajari ataupun dijadikan sebagai sumber dalam suatu penelitian untuk menarik kesimpulan.

tabel 1

komposisi populasi kelas V SD Gugus Kolonel I Gusti Ngurah Rai Denpasar Utara

\begin{tabular}{|c|c|c|c|c|c|}
\hline \multirow[t]{2}{*}{ No } & \multirow[t]{2}{*}{ Sekolah } & \multirow[t]{2}{*}{ Kelas } & \multicolumn{2}{|c|}{ Jumlah } & \multirow{2}{*}{$\begin{array}{c}\text { Jumlah } \\
\text { Siswa }\end{array}$} \\
\hline & & & Laki-laki & Perempuan & \\
\hline \multirow{4}{*}{1} & \multirow{4}{*}{ SD Negeri 1 Ubung } & VA & 18 & 17 & 35 \\
\hline & & VB & 17 & 18 & 35 \\
\hline & & VC & 17 & 18 & 35 \\
\hline & & VA & 14 & 14 & 28 \\
\hline \multirow[t]{2}{*}{2} & \multirow[t]{2}{*}{ SD Negeri 2 Ubung } & VB & 14 & 13 & 27 \\
\hline & & VC & 14 & 13 & 27 \\
\hline \multirow{2}{*}{3} & \multirow{2}{*}{ SD Negeri 3 Ubung } & VA & 19 & 20 & 39 \\
\hline & & VB & 19 & 17 & 36 \\
\hline \multirow{2}{*}{4} & \multirow{2}{*}{ SD Negeri 4 Ubung } & VA & 22 & 23 & 45 \\
\hline & & VB & 21 & 21 & 42 \\
\hline \multirow{2}{*}{5} & \multirow{2}{*}{ SD Negeri 5 Ubung } & VA & 13 & 12 & 25 \\
\hline & & VB & 12 & 12 & 24 \\
\hline \multirow{3}{*}{6} & \multirow{2}{*}{ SD Negeri 6 Ubung } & VA & 16 & 18 & 34 \\
\hline & & VB & 19 & 19 & 38 \\
\hline & Jumlah & & 238 & 237 & 470 \\
\hline
\end{tabular}

Berdasarkan informasi diatas yang diperoleh dari kepala sekolah serta guru kelas $\mathrm{V}$ di masing-masing SD Negeri Gugus Kolonel I Gusti Ngurah Rai Denpasar Utara yaitu bahwa kelas V dari 6 sekolah dengan 14 kelas yang ada di Gugus Kolonel I Gusti Ngurah Rai Denpasar Utara tidak terdapat kelas unggulan maupun non unggulan. Hal ini dilihat dari pengelompokan siswa ke dalam kelas-kelas dari 6 sekolah yang ada disebar secara merata Antara siswa yang memiliki kemampuan tinggi, sedang, dan rendah. Menurut sugiyono (2010:81), "sampel adalah bagian dari karakteristik yang dimiliki oleh populasi tersebut. Sampel merupakan bagian yang mewakili seluruh anggota populasi. Sampel yang diambil dari populasi harus betul-betul representative". Jadi dapat dismpulkan bahwa sampel adalah bagian yang mewakili anggota populasi yang dipilih dan diambil dengan menggunakan teknik tertentu. Teknik yang digunakan dalam menentukan sampel adalah teknik sampling. Menurut sugiyono (2010:81), "teknik sampling merupakan teknik pengambilan sampel". Sedangkan menurut Dantes (2012:40), "dalam menentukan teknik sampling ini terdapat berbagaai teknik sampling yang digunakan yaitu, probability sampling dan non probability sampling". 
Pengambilan sampel pada penelitian ini dilakukan dengan teknik Random Sampling pada kelas yang akan dijadikan kelompok kontrol dan kelompok eksperimen. "Random Sampling merupakan cara pengambilan sampel dengan memberikan kesempatan yang sama kepada anggota populasi untuk diambil menjadi anggota sampel" (Agung, 2014:71). Pemilihan sampel penelitian ini tidak dilakukan pengacakan individu tetapi hanya pengacakan kelas. Kelas dipilih telah terbentuk tanpa campur tangan peneliti dan tidak dilakukannya pengacakan individu, kemungkinan pengaruh-pengaruh dari keadaan siswa mengetahui dirinya dilibatkan dalam eksperimen dapat dikurangi yang mana penelitian ini dapat menggambarkan pengaruh perlakuan yang diberikan. Setelah melakukan random pada 14 kelas yang terdapat dalam populasi, yang didapatkan 2 kelompok sampel penelitiann yang berjumlah 470 siswa. Kedua kelompok itu diasumsikan setara dari segi akademik dan karakteristik. Hal ini juga diperkuat dari asumsi ketua gugus yang mana surat keterangan asumsi dilampirkan pada lampiran 10.

Dalam setiap penelitian khususnya eksperimen, terdapat ancaman dalam proses penelitian, hal ini berkaitan dengan kontrol validitas penelitian yang terbagi meenjadi dua yaitu kontrol validitas internal dan kontrol validitas eksternal. Kontrol validitas internal mencakup Kematangan atau Maturasi (Maturation), Menurut Setyosari, (2013: 183) "Maturasi atau kematangan merujuk pada proses perubahan yang terjadi dalam diri subjek yang dijadikan kelompok eksperimen". Untuk mendapatkan hasil penelitian yang valid maka dapat dilakukan cara yaitu, faktor kematangan ini dapat dikontrol dengan menggunakan kelompok kontrol yang memiliki kesamaan kematangan yang dilihat dari usia kelompok siswa di kedua sekolah yang dijadikan sampel penelitian, Instrumentasi merupakan pengukuran yang digunakan dalam penelitian pada tahap pemberian perlakuan (setyosari, 2015). Pada penelitian ini amcaman instrumentasi akan di kendalikan dengan pemilihan instrumen pengumpulan data yang tepat yaitu berupa tes pilihan ganda yang telah diuji validitas, uji daya beda, indeks kesukaran, dan uji reliabilitas Pada penelitian ini menggunakan instrumen berupa tes yang diberikan sesudah perlakuan. Pada posttest adalah tes dengan materi yang sudah dibelajarkan pada siswa pada saat diberikan perlakuan. Dengan instrumen tes yang diberikan berupa tes pilihan ganda biasa. Untuk melakukan penyetaraan kelas kontrol dengan kelas eksperimen digunakanlah posttestt. Kontrol Validitas Eksternal, Menurut Tuckman (dalam Setyosari, 2013: 192) menyatakan bahwa, validitas eksternal merujuk pada generalisasi atau representasi temuan-temuan penelitian dan berkenaan dengan seberapa jauh hasil penelitian dapat digeneralisasikan di luar latar penelitian. Ada salah satu cara yang dapat diupayakan untuk mengendalikan validitas eksternal yaitu dengan membatasi populasi. Menurut Setyosari (2013: 198) menyatakan bahwa membatasi populasi dapat memeperkecil adanya validitas eksternal dalam penelitian. Populasi dalam penelitian ini menggunakan sekolah dalam satu gugus yaitu seluruh siswa kelas V yang berada di gugus Kolonel I Gusti Ngurah Rai Denpasar Utara.Dalam metode pengumpulan data, data yang digunakan adalah tes. Menurut Muri Yusuf (2015:93),"pada prinsipnya suatu tes merupakan suatu prosedur sistematis untuk mengukur sampel tingkah laku seseorang". Data yang dikumpulkan dalam penelitian ini adalah data tentang kompetensi pengetahuan PPKn siswa kelas V SD Gugus Kolonel I Gusti Ngurah Rai Denpasar Utara, dengan perolehan data berupa skor hasil perolehan siswa yang dijadikan bahan penelitian. Jenis tes yang digunakan untuk menilai kompetensi pengetahuan siswa pada aspek kognitif adalah suatu tes kompetensi pengetahuan, yaitu dengan tes objektif berupa pilihan ganda. Tes objektif terdapat jawaban tes yang bersifat pasti, hanya satu kemungkinan jawaban yang benar. Tes objektif adalah tes yang disusun sedemikian rupa dan telah disediakan alternative jawabannya. Dalam penyusunan soal yang baik diperlukannya kisi - kisi, penulisan butir soal, penyekoran dan analisis butir soal yang perlu dikuasai. Pada tes objektif bentuk pilihan ganda biasa setiap butir soal yang dijawab benar mendapat skor 1 dan jika salah akan mendapat skor 0 pada setiap butir soal, hingga skor maksimal yang mampu diperoleh siswa adalah 30 dari 30 butir soal yang disediakan. Sebelum memberikan tes kepada sampel penelitian, terlebih dahulu dilakukan pengujian kelayakan instrumen. Tes yang harus memenuhi persyaratan uji validitas, uji daya beda, uji 
indeks kesukaran dan uji reliabilitas. Data dalam penelitian ini menggunakan statistik dekriptif dan statistik inferensial. Data yang dianalisis adalah nilai posttest.

Analisis data yang sudah didapat menggunakan analisis statistik deskriptif dan analisis statistik infenrensial. "statistik deskriptif adalah statistik yang digunakan unuk mengnalisis data dengan cara mendeskripsikan tau menggambarkan data yang telah terkumpul adanya tanpa bermaksud membuat kesimpulan yang berlaku untuk umum atau generalisasi" (Sugiyono, 2015:207-208). "statistik deskriptif adalah suatu cara pengolahan data yang dilakukan dengan jalan menerapkan rumur-rumus statistic deskriptif untuk menggambarkan suattu objek atau variabel tertentu, sehingga diperoleh keimpulan umum" (Agung, 2014: 110). Jadi dapat rangkum dari beberapa pengertian diatas statistic deskriptif adalah cara pengolahan data cara mendeskripsikan data yang sudah berkumpul tanpa bermaksud membuat kesimpulan yang berlaku untuk umum. Penyajian data penelitian ini dengan perolehan rata - rata yang menggunakan perhitungan statistik Mean (M) dengan rumus sebagai berikut. Teknik analisis statistik deskriptif yang digunakan diantaranya menentukan nilai rerata (mean), simpangan baku dan varians. Sedangkan metode analisis inferensial digunakan teknik analisis data yang dilakukan adalah uji hipotesis menggunakan uji t, sebelum dilakukan uji hipotesis, terlebih dahulu dilakukan uji prasyarat analisis data yaitu uji normalitas sebaran data dan uji homogenitas varians.

Tujuan dilakukannya uji normalitas data adalah untuk mengetahui apakah uji hipotesis dengan statistik parametrik bisa dilakukan atau tidak dan untuk mengetahui apakah sebaran data skor prestasi belajar PPKn siswa masing-masing kelompok berdistribusi normal, Sedangkan, bila data tidak berdistribusi normal maka uji lanjut menggunakan statistik parametrik tidak bisa dilakukan dan harus beralih menggunakan statistik nonparametrik. Untuk mengetahui apakah sebaran data kompetensi pengetahuan siswa berdistribusi normal atau tidak maka digunakan teknik analisis Chi-Square, Hasil $\mathrm{x}^{2}$ hitung kemudian dibandingkan dengan $\mathrm{x}^{2}$ tabel pada taraf signifikansi $5 \%$ dan derajad kebebasan (dk). Jika $x^{2}$ hitung $\leq x^{2}$ tabel, maka data berdistribusi normal. Jika $x^{2}$ hitung $>$ $x^{2}$ tabel, maka data tidak berdistribusi normal. Dalam Uji kesamaan dua varians digunakan untuk menguji apakah sebaran data homogen atau tidak, yaitu dengan membandingkan variansnya. Uji homogenitas dilakukan untuk menunjukan bahwa perbedaan yang terjadi pada uji hipotesis benar-benar terjadi akibat adanya perbedaan varians antara kelompok, bukan sebagai akibat perbedaan dalam kelompok. Uji homogenitas dapat dilakukan apabila kelompok data tersebut berdistribusi normal. Uji homogenitas untuk kedua kelompok digunakan uji $F$, dengan kriteria pengujian untuk mengetahui data yang mempunyai varians yang homogen yaitu, jika maka sampel tidak homogen dan jika maka sampel homogen. Pengujian dilakukan pada taraf signifikansi 5\% dengan derajat kebebasan untuk pembilang n_1 - 1 dan derajat kebebasan untuk penyebut n_2-1. Jika data yang diperoleh sudah memenuhi prasyarat uji normalitas dan homogenitas maka analisis yang digunakan adalah statistik parametrik. Analisis statistik yang digunakan untuk menguji hipotesis penelitian ini adalah uji beda rerata (uji t). Uji Hipotesis menggunakan uji-t dengan rumus Polled varians. Dengan kriteria pengujian jika harga thitung < ttabel, maka Ho diterima dan Ha ditolak, dan jika harga thitung > ttabel maka Ho ditolak dan Ha diterima. Pada taraf signifikansi 5\% dengan $\mathrm{dk}=\mathrm{n} 1+\mathrm{n} 2-2$.

$$
t=\frac{\overline{\overline{X_{1}}}+\overline{X_{2}}}{\sqrt{\frac{\left(n_{1}-1\right) S_{1}^{2}+\left(n_{2}-1\right) S_{2}^{2}}{n_{1}+n_{2}-2}\left[\frac{1}{36}+\frac{1}{34}\right]}}
$$

(Sugiyono, 2017:138)

keterangan

$\overline{X_{1}}=$ rata-rata kelompok eksperimen

$\frac{X_{1}}{X_{2}} \quad=$ rata-rata kelompok control 
$S_{1}^{2}=$ Varians sampel kelompok eksperimen

$S_{2}^{2}=$ Varians sampel kelompok control

$\mathrm{n}_{1}$ = Jumlah sampel kelompok eksperimen

n2 = jumlah sampel kelompok kontrol

\section{Hasil dan Pembahasan}

Data yang diperoleh dalam penelitian ini dikelompokkan menjadi dua yaitu : (1) data kompetensi pengetahuan PPKn kelompok kelas eksperimen, (2) data kompetensi pengetahuan PPKn kelompok kelas kontrol. Tingkat hasil belajar PPKn siswa dapat ditentukan ke dalam PAN skala 5 yang dapat disimpulkan Distribusi Data Kompetensi Pengetahuan PPKn pada tabel PAN Skala Lima di kelas eksperimen, yang memperoleh nilai 73 sebanyak 4 orang siswa memiliki kategori kurang, yang memperoleh nilai 77 sebanyak 6 orang siswa dan memperoleh nilai 80 sebanyak 9 orang siswa memiliki kategori cukup, yang memperoleh nilai 83 sebanyak 7 orang siswa memiliki kategori baik. Serta yang memperoleh nilai 87, 90 sebanyak 10 orang siswa memiliki kategori sangat baik. Sedangkan dalam dalam kelas Kontrol dapat disimpulkan Distribusi Data Kompetensi Pengetahuan PPKn pada tabel PAN Skala Lima, yang memperoleh nilai 63 sebanyak 8 orang siswa memiliki kategori sangat kurang, yang memperoleh nilai 67 sebanyak 9 orang siswa dan memperoleh nilai 70 sebanyak 7 orang siswa memiliki kategori cukup, yang memperoleh nilai 73 sebanyak 5 orang siswa memiliki kategori baik. Serta yang memperoleh nilai 77, 80 sebanyak 5 orang siswa memiliki kategori sangat baik. Dapat dirangkum bahwa kelas eksperimen dan kelas control masuk ke dalam kategori cukup dalam tabel PAN skala 5.

tabel 2

PAN Skala 5 pada kelas Eksperimen

\begin{tabular}{c|c|c}
\hline Rentang & Hasil & Kategori \\
\hline$M+1,5$ SD $\rightarrow M+3,0$ SD & $86,34 \rightarrow 93,66$ & Sangat Baik \\
$M+0,5 S D \rightarrow M+1,5$ SD & $81,46 \rightarrow 86,34$ & Baik \\
$M-0,5 S D \rightarrow M+0,5$ SD & $76,58 \rightarrow 81,46$ & Cukuo \\
$M-1,5 S D \rightarrow M-0,5$ SD & $71,70 \rightarrow 76,58$ & Kurang \\
$M-3,0 S D \rightarrow M-1,5 S D$ & $71,70 \rightarrow 71,70$ & Sangat Kurang \\
\hline
\end{tabular}

tabel 3

PAN Skala 5 pada kelas Kontrol

\begin{tabular}{c|c|c}
\hline Rentang & Hasil & Kategori \\
\hline$M+1,5$ SD $\rightarrow M+3,0$ SD & $76,35 \rightarrow 83,33$ & Sangat Baik \\
\hline$M+0,5$ SD $\rightarrow M+1,5$ SD & $71,79 \rightarrow 76,35$ & Baik \\
\hline$M-0,5 S D \rightarrow M+0,5$ SD & $67,05 \rightarrow 71,79$ & Cukup \\
\hline$M-1,5 S D \rightarrow M-0,5 S D$ & $62,41 \rightarrow 67,05$ & Kurang \\
\hline$M-3,0 S D \rightarrow M-1,5 S D$ & $62,41 \rightarrow 62,41$ & Sangat Kurang \\
\hline
\end{tabular}

Rekapitulasi hasil perhitungan analisis deskriptif disajikan pada tabel berikut:

tabel 4

Rekapitilasi Hasil Analisis Deskriptif

\begin{tabular}{cccccc}
\hline No & Sampel & Mean & SD & $\begin{array}{c}\text { VARIA } \\
\text { NS }\end{array}$ & RANGE \\
\hline 1 & Kelas VB SD Negeri 3 Ubung & 79,02 & 4,88 & 23,81 & 18 \\
2 & Kelas VA SD Negeri 6 Ubung & 69,38 & 4,65 & 21,69 & 18 \\
\hline
\end{tabular}


Dalam Pengujian Uji Normalitas dilakukan untuk setiap data pada setiap sel, yakni: (1) kompetensi pengetahuan PPKn siswa yang mengikuti pembelajaran Model Quantum Teaching Berbasis Tri Hita Karana dan (2) kompetensi pengetahuan PPKn siswa yang mengikuti pembelajaran Model Konvensional. Uji normalitas dilakukan untuk mengetahui normal atau tidaknya suatu data. Uji normalitas sebaran data yang digunakan dalam penelitian ini menggunakan teknik analisis Chi-Square. Hasil $\mathrm{x}^{2}$ hitung kemudian dibandingkan dengan $\mathrm{x}^{2}$ tabel pada taraf signifikansi $5 \%$ dan derajad kebebasan (dk). Jika $\mathrm{x}^{2}$ hitung $\leq \mathrm{x}^{2}$ tabel, maka data berdistribusi normal. Harga tersebut kemudian dikonsultasikan denan harga $X^{2}$ tabel dengan $\mathrm{dk}=5$ dan taraf signifikan $5 \%$ sehingga diperoleh harga $X^{2}$ tabel $=11,070$. Karena $X^{2}$ hitung $=8,64 \leq X^{2}$ tabel $=11,070$, hasil perhitungan tabel kerja uji normalitas sebaran data kelompok eksperimen diperoleh nilai $X^{2}$ hitung $=8,64$. Berdasarkan perhitungan tersebut didapatkan $X^{2}$ hitung $=8,64 \leq X^{2}$ tabel $=11,070$ hal tersebut menunjukkan bahwa data hasil kompetensi pengetahuan PPKn di kelompok eksperimen berdistribusi normal. Hasil $x^{2}$ hitung kemudian dibandingkan dengan $x^{2}$ tabel pada taraf signifikansi $5 \%$ dan derajad kebebasan (dk). Jika $x^{2}$ hitung $\leq x^{2}$ tabel, maka data berdistribusi normal. Harga tersebut kemudian dikonsultasikan denan harga $X^{2}$ tabel dengan $\mathrm{dk}=5$ dan taraf signifikan $5 \%$ sehingga diperoleh harga $X^{2}$ tabel $=11,070$. Karena $X^{2}$ hitung $=10,25 \leq X^{2}$ tabel $=11,070$, hasil perhitungan tabel kerja uji normalitas sebaran data kelompok eksperimen diperoleh nilai $X^{2}$ hitung $=10,25$. Berdasarkan perhitungan tersebut didapatkan $X^{2}$ hitung $=10,25 \leq X^{2}$ tabel $=11,070$ hal tersebut menunjukkan bahwa data hasil kompetensi pengetahuan PPKn di kelompok eksperimen berdistribusi normal.

tabel 5

Rekapitilasi Hasil Analisis Uji Normalitas sebaran data

\begin{tabular}{ccccc}
\hline No & Sampel & $\mathrm{X}^{2}$ hitung & $\mathrm{X}^{2}$ tabel & Keterangan \\
\hline 1 & Kelas VB SD Negeri 3 Ubung & 8,64 & & Berdistribusi Normal \\
2 & Kelas VA SD Negeri 6 Ubung & 10,25 & 11,070 & \\
\hline
\end{tabular}

Pengujian homogenitas dilakukan untuk menguji kesamaan varians setiap kelompok data dan untuk meyakinkan bahwa perbedaan yang diperoleh uji-t benar - benar berasal dari perbedaan antar kelompok. Uji homogenitas varians yang dilakukan dalam penelitian ini menggunakan uji $\mathrm{F}$ (uji Fisher) dengan kriteria pengujian, jika $F_{\text {hit }}>F_{\text {tabel }}$ maka sampel tidak homogen dan jika $F_{\text {hit }}<F_{\text {tabel }}$ maka sampel homogen. Pengujian dilakukan pada taraf signifikansi $5 \%$ dengan derajat kebebasan untuk pembilang $n_{1}-1$ dan derajat kebebasan untuk penyebut $n_{2}-1$.berdasarkan hasil perhitungan varians, uji homogenitas varians data kompetensi pengetahuan PPKn kelompok eksperimen dan kelompok control diperoleh $F_{\text {hitung }}=1,10$. Nilai tersebut kemudian dikonsultasikan dengan harga $F_{\text {tabel }}$ dengan taraf signifikansi $5 \%$ dengan derajat kebebasan (dk 1) untuk pembilang $\mathrm{n} 1-1$ = 36 -1 dan derajat kebebasan ( $\mathrm{dk} 2$ ) untuk penyebut n2-1 = 34-1. Jadi dapat dianalisis $F_{\text {tabel }}=1,80$, karena $F_{\text {hitung }}=1,10 \leq F_{\text {tabel }}=1,80$ maka dapat dikatakan bahwa data kompetensi pengetahuan PPKn pada kelompok eksperimen dan kelompok control mempunyai varians yang homogen.

tabel 6

Rekapitilasi Hasil Analisis Uji Homogenitas Varians

\begin{tabular}{ccccc}
\hline No & Sampel & $F_{\text {hitung }}$ & $F_{\text {tabel }}$ & $\begin{array}{c}\text { Keterangan } \\
\text { Homogen }\end{array}$ \\
\hline
\end{tabular}




2 Kelas VA SD Negeri 6 Ubung $1,10 \quad$ Homogen

Tabel 7

Rekapitilasi Hasil Analisis Uji t-test

\begin{tabular}{cccc}
\hline No & Sampel & $t_{\text {hitung }}$ & ttabel \\
\hline 1 & Kelas VB SD Negeri 3 Ubung & & 2,000 \\
2 & Kelas VA SD Negeri 6 Ubung & 8,239 & \\
\hline
\end{tabular}

Berdasarkan hasil uji normalitas sebaran data dan uji homogenitas varians dapat diketahui bahwa data yang diperoleh dari kelompok kelas eksperimen dan kelompok kelas kontrol berdistribusi normal dan memiliki varians yang homogen. Karena data yang telah diperoleh telah memenuhi uji prasyarat analisis, maka uji hipotesis yang dapat dilakukan dengan menggunakan analisis statistik parametrik dengan uji-t sparated varians. Berdasarkan hasil perhitungan uji-t diperoleh thitung $=8,239$. Sedangkan nilai ttabel pada taraf signifikansi $5 \%$ dengan $\mathrm{dk}=\mathrm{n} 1+\mathrm{n} 2-2=36+34-2=68$ menunjukkan nilai ttabel sebesar 2,000. Sehingga diperoleh hasil analisis nilai thitung $>$ ttabel yaitu 8,239 $>2,000$ maka $\mathrm{Ho}$ ditolak dan $\mathrm{Ha}$ diterima. Itu berarti pula bahwa hipotesis $\mathrm{H}_{0}$ yang menyatakan tidak terdapat perbedaan yang signifikan kompetensi pengetahuan PPKn antara kelompok eksperimen dan kelompok kontrol pada kelas V SD Gugus Kolonel I Gusti Ngurah Rai Denpasar Utara tahun pelajaran 2018/2019, ditolak. Dan Ha diterima yang menyatakan terdapat perbedaan yang signifikan kompetensi pengetahuan PPKn antara kelompok eksperimen dan kelompok kontrol pada kelas V SD Gugus Kolonel I Gusti Ngurah Rai Denpasar Utara tahun pelajaran 2018/2019. Dengan demikian dapat ditarik kesimpulan bahwa terdapat perbedaan yang signifikan kompetensi pengetahuan PPKn antara kelompok eksperimen dan kelompok kontrol pada kelas V SD Gugus Kolonel I Gusti Ngurah Rai Denpasar Utara tahun pelajaran 2018/2019.

\section{SIMPULAN}

Berdasarkan pemaparan artikel yang telah diuraikan sebelumnya, dapat disimpulkan sebagai berikut. Berdasarkan hasil penelitian dan pembahasan dari analisis data, kompetensi pengetahuan PPKn kelompok siswa yang dibelajarkan dengan model Quantum Teaching berbasis Tri Hita Karana juga dapat disimpulkan bahwa Distribusi Data Kompetensi Pengetahuan PPKn pada tabel PAN Skala Lima, yang memperoleh nilai 73 sebanyak 4 orang siswa memiliki kategori kurang, yang memperoleh nilai 77 sebanyak 6 orang siswa dan memperoleh nilai 80 sebanyak 9 orang siswa memiliki kategori cukup, yang memperoleh nilai 83 sebanyak 7 orang siswa memiliki kategori baik. Serta yang memperoleh nilai 87, 90 sebanyak 10 orang siswa memiliki kategori sangat baik. dapat disimpulkan bahwa Distribusi Data Kompetensi Pengetahuan PPKn pada tabel PAN Skala Lima, yang memperoleh nilai 63 sebanyak 8 orang siswa memiliki kategori sangat kurang, yang memperoleh nilai 67 sebanyak 9 orang siswa dan memperoleh nilai 70 sebanyak 7 orang siswa memiliki kategori cukup, yang memperoleh nilai 73 sebanyak 5 orang siswa memiliki kategori baik. Serta yang memperoleh nilai 77, 80 sebanyak 5 orang siswa memiliki kategori sangat baik. Untuk kompetensi pengetahuan PPKn kelompok siswa yang dibelajarkan dengan model pembelajaran konvensional dapat disimpulkan bahwa Distribusi Data Kompetensi Pengetahuan PPKn pada tabel PAN Skala Lima, yang memperoleh nilai 63 sebanyak 8 orang siswa memiliki kategori sangat kurang, yang memperoleh nilai 67 
sebanyak 9 orang siswa dan memperoleh nilai 70 sebanyak 7 orang siswa memiliki kategori cukup, yang memperoleh nilai 73 sebanyak 5 orang siswa memiliki kategori baik. Serta yang memperoleh nilai 77,80 sebanyak 5 orang siswa memiliki kategori sangat baik.

Hasil Uji Hipotesis, diperoleh $t_{\text {hitung }}=8,239$ dan $t_{\text {tabel }}=2,000$ pada taraf signifikansi $5 \%$ dengan $d k=n 1+n 2-2=68$. Ini berarti $t_{\text {hitung }}>t_{\text {tabel }}(8,239>2,000)$. Itu berarti pula bahwa hipotesis $\mathrm{H}_{0}$ yang menyatakan tidak terdapat perbedaan yang signifikan kompetensi pengetahuan PPKn antara kelompok eksperimen dan kelompok kontrol pada kelas V SD Gugus Kolonel I Gusti Ngurah Rai Denpasar Utara tahun pelajaran 2018/2019, ditolak. Dan Ha diterima yang menyatakan terdapat perbedaan yang signifikan kompetensi pengetahuan PPKn antara kelompok eksperimen dan kelompok kontrol pada kelas V SD Gugus Kolonel I Gusti Ngurah Rai Denpasar Utara tahun pelajaran 2018/2019. Dengan demikian dapat ditarik kesimpulan bahwa terdapat perbedaan yang signifikan kompetensi pengetahuan PPKn antara kelompok eksperimen dan kelompok kontrol pada kelas V SD Gugus Kolonel I Gusti Ngurah Rai Denpasar Utara tahun pelajaran 2018/2019.

\section{DAFTAR PUSTAKA}

Agung, Gede. 2011. Pengantar Evaluasi Pendidikan. Singaraja: Universitas Pendidikan Ganesha Singaraja.

Agung, Gede. 2016. Statistika Dasar untuk Pendidikan. Yogyakarta: DEEPUBLISH.

Arikunto. 2015. Dasar-dasar Evaluasi Pendidikan. Jakarta: Bumi Aksara .

Asef. 2011. Permendiknas Nomor 22 Tahun 2006. Tersdia pada https://asefts63.files.wordpress.com/2011/01/permendiknas-no-22-tahun-2006-

standar-isi.pdf (diakses tanggal 21 Februari 2019, pukul 17.00). Bumi Aksara.

Candisa, Made. 2004. Statistik Multivariat dilengkapi dengan SPSS. Singaraja: Unit Penerbitan IKIP Negeri Singaraja

Dantes. 2012. Metode Penelitian. Yogyakarta: CV Andi Offset.

Dantes, Nyoman. 2017. Desain Eksperimen dan Analisis Data. Depok: PT Raja Gravindo Persada.

DePorter, Bobbi. 2014. Quantum Teaching. Bandung: Kaifa.

Ihsan. 2017. Kecenderungan Global Dalam Proses Pembelajaran Pendidikan Pancasila dan

Kewarganegaraan di Sekolah. Tersedia Pada http://journal.umpo.ac.id/index.php/

JPK/index (diakses tanggal 16 Maret, pukul 15.00)

Ikhsanudin, Eka. 2014. Permendikbud RI Nomor 57 Tahun 2014. Tersedia pada

https://www.ekaikhsanudin.net/2014/09/permendikbud-ri-nomor-57-tahun-2014.html

(diakses tanggal 21 Februari 2019, pukul 13.50).

Jakni, S.Pd. 2014. Pendidikan Kewarganegaraan di Perguruan Tinggi. Bandung: Alfabeta

Kurniasih, dan Berlin Sani. 2016. Revisi Kurikulum 2013. Jakarta: Kata Pena.

Kosasih, E. 2014. Strategi Belajar dan Pembelajaran. Bandung: Yrama Widya.

Koyan. 2012. Statistik Teknik Analisis Data Kuantitatif. Singaraja: Universitas Pendidikan

Ganesha

Sang Made Sarwadana. 2016. Aplikasi Tri Hita Karana. Bali: Kayumas Agung

Setyosari, Punaji. 2013. Metode Penelitian Pendidikan dan Pengembangan. Jakarta:

Prenamedia Group

Setyosari,Punaji. 2015. Metode Penelitian Pendidikan dan Pengembangan. Jakarta:

Prenada Media Group

Sudijono, Anas. 2011. Pengantar Evaluasi Pendidikan. Jakarta: Rajagrafindo Persada 
Sugiyono, 2010. Metode Penelitian Kuantitatif Kualitatif dan R\&D. Bandung: Alfabeta Sugiyono. 2016. Metode Penelitian Kuantitatif, Kualitatif, dan R\&D. Bandung: Alfabeta Sumarna, Dede. 2013. Pembelajaran Quantum dan Optimals Kecerdasan. Bandung: Alfabeta

Susanto, Ahmad. 2013. Teori Belajar dan Pembelajaran di Sekolah Dasar. Jakarta: Kencana Thobroni. 2015. Belajar dan Pembelajaran Teori dan Praktik. Yogyakarta: Ar-Ruzz Media Trianto, S.Pd., M.Pd. 2007. Model-model Pembelajaran Inovatif berorientasi Konstruktivistik. Jakarta: Prestasi Pustaka

Triwiyanto, Teguh. 2014. Pengantar Pendidikan. Jakarta: Bumi Aksara

Wina Sanjaya, Prof. Dr. H. 2010. Kurikulum dan Pembelajaran. Jakarta: Kencana

Winataputra, dkk. 2006. Materi dan Pembelajaran PKN SD. Jakarta: Universitas Terbuka Yusuf, Muri. 2015. Asesmen dan Evaluasi Pendidikan. Jakarta: Kencana 